\title{
A ARTE DO ENCONTRO: A EDUCAÇ̃̃O ESTÉTICA AMBIENTAL ATUANDO COM O TEATRO DO OPRIMIDO
}

\author{
Eduardo Silveira*
}

RESUMO: A educação ambiental tem a tarefa de buscar novas formas de relacionamento entre ser humano e natureza, pautadas em um posicionamento ético, mas carrega as dificuldades impostas por um modelo de educação engessado, pautado na lógica da racionalidade técnico-científica que permeia toda a sociedade. Na tentativa de superar essa condição, propomos a educação estética ambiental como forma de o ser humano relacionar-se com o mundo que habita, tendo o desafio de provocar o reencontro do humano com as dimensões sensível, afetiva e poética que o compõem. Tendo este campo como fundamento, buscamos, teoricamente, refletir sobre a inserção de uma proposta artística como meio de se chegar aos objetivos necessários à educação ambiental. No campo da arte, voltamo-nos ao teatro do oprimido, que tem como principal objetivo a democratização do teatro, considerada atividade orgânica do ser humano. Identificamos nele aproximações com os princípios e objetivos buscados pela educação estética ambiental.

Palavras-chave: Educação Ambiental; Educação Estética; Teatro do Oprimido.

\section{THE ART OF MEETING:}

THE AESTHETIC ENVIRONMENTAL EDUCATION ACTING WITH THE THEATER OF THE OPPRESSED ABSTRACT: The environmental education is aimed at seeking new forms of relationship between human beings and nature. Although based on an ethical position, it carries the difficulties imposed by a plaster model of education, based on the logic of technicalscientific rationality that permeates society. In an attempt to overcome such condition we propose the aesthetic environmental education as a way of human beings to relate with the world they inhabit while posing the challenge to lead the reunion with their sensitive, emotional and poetic dimensions. Having this field as a basis, we, theoretically, reflect on the inclusion of an artistic proposal as a means of achieving the necessary goals for the environmental education. In the field of art, we turn to the theater of the oppressed, which has the goal of theater democratization, as an organic activity of human beings. We have identified in it approximations to the principles and objectives sought by the aesthetic environmental education.

Keywords: Environmental Education; Aesthetic Education; Theater of the Oppressed.

\footnotetext{
* Professor substituto de Didática na Universidade Federal do Paraná (UFPR); Biólogo e Mestre em Educação pela Universidade Federal do Paraná (UFPR); Ator amador. E-mail: dubio@ufpr.br.
} 


\section{Introdução}

A educação ambiental surgiu enquanto campo do conhecimento com o intuito de questionar valores, buscar novas posições do ser humano em relação ao ambiente e, com isso, levar a um posicionamento ético. Desde seu início, décadas atrás, ela vem se modificando, buscando firmar-se, cada vez mais, no campo educativo, em vez de se posicionar exclusivamente no seio do movimento ambientalista através do ensino de ciências e ecologia com caráter conservacionista. Assim, novas possibilidades têm surgido como importantes aportes, como aquelas que expandem o campo da educação ambiental, privilegiando novos diálogos com campos como a Filosofia, a Sociologia e a Arte. É justamente neste último que focamos nossa atenção, na dimensão estética da educação que considera a necessidade de buscar, na ressensibilização do ser humano, através da criação de novos espaços de subjetividade e modos de viver, uma alter-nativa ao enrijecimento do humano pela atitude fria da racionalidade técnico-científica moderna, que permeia toda a sociedade e faz-se presente também no campo educacional.

Já se pode perceber, nesta sucinta apresentação, que os objetivos da educação estética, quando propõe a necessidade de buscar a concretude do ser humano, dando vazão às outras dimensões deste, como a afetiva, poética e sensível, se relacionam intimamente com os da educação ambiental que procura, através da problematização da relação ser humano-ambiente, levar a um posicionamento ético. Assim, através da proposição de um espaço convergente entre esses campos, propomos a educação estética ambiental ${ }^{1}$ como mais uma opção para o enriquecimento das concepções no campo da educação ambiental e como meio de se contrapor aos reducionismos que se multiplicam em algumas proposições em educação ambiental e que são comentados por diversos autores do campo, como Gaudiano (2007), Lima (1999), Marin (2005; 2006; 2007), Tristão (2004; 2005), entre outros.

Tendo como fundamento a educação estética ambiental, buscamos refletir sobre a inserção de uma proposta artística como meio de se chegar aos objetivos necessários a uma educação ambiental efetiva. Nestas reflexões, voltamo-nos ao teatro e, mais especificamente, ao teatro do oprimido, metodologia teatral criada na década de 1970, no Brasil, pelo teatrólogo Augusto Boal. Ela pode ser definida como um método 
formado pelo conjunto de vários sistemas teatrais que, de maneira geral, buscam, por meio da experiência estética e da desmecanização do corpo, levar os sujeitos (atores, espectadores) ao reconhecimento e ao enfrentamento das situações de "opressão" a que estão submetidos. Isso torna-se possível pelo despertar da atitude crítica com base em um posicionamento ético e solidário.

O teatro do oprimido é composto por vários elementos teatrais com características próprias que podem ser usados em diferentes circunstâncias, como o teatro fórum, o teatro imagem, o teatro invisível e o teatro legislativo, entre outros. Com base nessa caracterização do teatro do oprimido e a partir da análise de seus fundamentos e práticas, consideramos que ele pode trazer muitas contribuições à educação estética ambiental.

\section{A educação ambiental e a educação estética}

A educação ambiental tem sua identidade revelada na própria denominação, que, por muitas vezes, foi desconsiderada na sua definição. Tal identidade diz respeito ao fato de ser proposta como educação, e não como mera estratégia de correção técnica e imediatista de problemas ambientais, como se pensava no início dos discursos ambientalistas:

A Educação Ambiental está ligada a dois desafios vitais: a questão da perturbação dos equilíbrios ecológicos, dos desgastes da natureza, e a questão da educação. Os desequilíbrios e a educação são heranças de um modelo de desenvolvimento socioeconômico que se caracteriza pela redução da realidade a seu nível material econômico, pela divisão do conhecimento em disciplinas que fragmentam a realidade, pela redução do ser humano a um sujeito racional, pela divisão das culturas, enfim. O campo da educação e o ambiental encontram-se fortemente marcados por essa ideologia cientificista que se impõe globalmente, em nome de uma racionalidade da ciência moderna. (TRISTÃO, 2005 p. 253-254)

Concepções de educação ambiental meramente voltadas para a conservação da natureza e para a correção de urgências ambientais, atravessadas por um discurso normativo, revelando, portanto, caráter marcadamente instrumental, como o colocado por Tristão, felizmente têm sido superadas em favor de uma definição mais complexa: 
Desse modo, a narrativa da Educação Ambiental, com freqüência, atravessada por essas premissas previamente aceitas, vem legitimar uma racionalidade colonizada que controla, constrói e destrói o meio ambiente. Essa cultura epidemiológica de sistemas universalistas parece estar num beco sem saída. [...] Então, a saída é refletirmos sobre os caminhos explicativos que temos seguido, sobre os perigos da padronização exaustiva dos nossos discursos e tentar encontrar outros caminhos possíveis ao caminhar, estratégias mais solidárias em relação ao meio ambiente e novos rumos que nos possibilitem uma viagem ao desconhecido. (TRISTÃO, 2005, p. 256)

Essa complexidade não é gerada somente no intricado desafio proposto pelos movimentos ambientalistas, mas especialmente por se tratar, antes de qualquer ação diretiva, de um processo educativo. As demandas atuais apresentadas à educação ambiental - formação de novos valores, ressignificação da relação sociedade-ambiente, ressensibilização do ser humano e dos seus modos de viver, etc. - não poderiam exigir menos que um movimento transformador, ou seja, um processo de educar.

Evidentemente, quando o primeiro termo destaca-se na definição de significados, a educação ambiental aloca-se definitivamente no campo da educação, mais precisamente, naquela dimensão do campo que abriga os conhecimentos transdisciplinares. Ao assim posicionar-se, naturalmente a educação ambiental passa a incorporar fundamentos do campo da educação e, por consequência, também suas fragilidades e indeterminações. Estas dizem respeito essencialmente ao caráter racionalista e instrumental, que, juntamente com o cartesianismo, viria a ser constante na educação desde o advento da modernidade clássica ${ }^{2}$, a partir do século XVII, ancorando-se na mudança de perspectiva no pensamento humanista para o científico (GADOTTI, 1995, p. 78). Essas características, juntamente com o advento do positivismo no século XIX, inculcando a visão de que a única forma de se estar preparado para a vida em sociedade é a partir do desenvolvimento intelectual e moral baseado no conhecimento científico e fragmentado, marcam a educação atual como um instrumento pelo qual o ser humano pode desenvolver todas as suas potencialidades cognitivas, por meio da transmissão do conhecimento científico pragmático, necessário ao enfrentamento dos problemas imediatos que a vida impõe.

Alguns desses fundamentos revelam-se, nesse processo, incompatíveis com as proposições da educação ambiental e da educação de 
forma geral, o que força uma busca de processos educativos e de reflexões teóricas que mais se aproximem de suas expectativas e que são, nesse sentido, considerados inovadores.

É nesse espaço que ganha importância a educação estética. Seu caráter inovador diz respeito somente ao fato de que, no modelo educacional corrente, a dimensão estética da educação é praticamente desconsiderada e esquecida, apesar de sua inquestionável importância. Para, portanto, demarcar o início do argumento em prol dessa importância, tomamos as palavras de Rudolf Steiner, idealizador da teoria antroposófica, que fundamenta a Pedagogia Waldorf e que, na obra $A$ arte da educação I (1988), apresenta a necessidade de a educação responsabilizar-se pela formação afetiva do educando: " $\mathrm{Na}$ educação e no ensino do futuro, deverá ser atribuído um valor muito especial ao cultivo da vontade e da vida afetiva. Mesmo aqueles que não cogitam de uma reforma do ensino e da educação afirmam a necessidade de se dar especial consideração à educação volitiva e emotiva" (STEINER, 1988, p. 52).

Ao propormos a educação estética, utilizamos o termo "estética" em sentido amplo, ou seja, fazendo referência a tudo o que envolve a dimensão sensível do humano, incluindo a possibilidade de estar inserido no mundo que o cerca, encarnado nesse mundo, percebendo os diferentes fenômenos que ele lhe oferece a todo momento, significando e expressando-o constantemente. Educar esteticamente significaria, nesse sentido, trabalhar com a sensibilidade e a percepção do que ainda não está formatado pela ciência e pela moral, dando condições ao sujeito de reencontrar-se livremente com o mundo que o cerca, de reconhecer sua naturalidade e a natureza deste mundo, de perceber em sua subjetividade as marcas da cultura e do ambiente vivido, de reconhecer, na sua história de vida, as construções compartilhadas com os outros. Essas percepções dão ao sujeito a possibilidade de indeterminação, de reconstrução de sua subjetividade, de adoção de novos valores e modos de viver, ao mesmo tempo em que lhe abrem a opção de pertencimento a um contexto histórico-cultural e a um lugar habitado:

Falamos em educação estética como um caminho capaz de reverter os três principais elementos do desligamento humano discutidos acima: o reconhecimento e valorização dos elementos topofilicos e identitários que ligam o humano aos seus lugares; o reavivamento do sentido da coletividade, na medida em que a sensibilidade abre aos âmbitos de vivência, e o aspecto erótico e envolvente das vivências concretas. (MARIN, 2007, p. 114) 
Nesse sentido, a educação estética possibilita primeiramente esse reencontro com o mundo que o cerca, tornando o ser consciente do lugar que habita e que o circunda. Em um segundo momento, esse reencontro possibilita o despertar de dimensões há muito adormecidas e que são essenciais na busca de um ser humano integral que possa agir nesse mundo reconhecido e habitado esteticamente. Dessas dimensões, há muito desconsideradas pela racionalidade técnico-científica, fazem parte a afetiva, a poética, a criativa e a imaginativa. Duarte Júnior (1981, p. 55, grifo do autor) sinaliza um significado para essa educação: “ (...) educar significa, basicamente, permitir ao indivíduo a eleição de um sentido que norteie sua existência. Significa permitir que ele conheça as múltiplas significações e as compreenda a partir de suas vivências".

Nosso conhecimento sobre o mundo é dado pelos significados que criamos, ancorados em nossas experiências, e nossas experiências se baseiam em percepções que temos do mundo e em como somos atingidos por essas percepções. Assim, podemos pontuar que, ao atentarmos para como somos atingidos pelos fenômenos que nos cercam, como os captamos com todas as dimensões que nos compõem, já estaríamos nos educando esteticamente, pois só se torna relevante para nossa existência aquilo que conseguimos ancorar em nossas vivências para, depois, significá-las:

Todo conhecimento humano é gerado num momento de percepção de mundo. As imagens que o mundo oferece ao humano despertam sua criatividade, seu desejo de conhecer e sua imaginação. Educar, nesse sentido, é um fenômeno que deve permitir o afloramento dessas prerrogativas. Não há educação sem que haja encontro com as realidades valiosas, com o mundo que inspira, na natureza humana, razão, imaginação e emoção. (MARIN; OLIVEIRA; COMAR, 2005, p. 200)

Já tendo delineado a maneira pela qual a educação estética pode suplantar as limitações impostas ao desenvolvimento integral do ser humano, cabe analisar onde ela se ancora nas proposições que defende. Essa análise será fundamental também para a contextualização do campo da educação estética ambiental na sequência. 


\section{As bases da educação estética}

A educação estética propõe o reencontro do ser humano com suas dimensões fluidas, com o mundo que o cerca, com suas vivências e o reconhecimento do lugar habitado. Essas proposições não podem ter seu embasamento nas representações e nos conceitos ventilados pelo pensamento clássico, que leva à perda da materialidade e da dinamicidade dos fenômenos. Tudo se passa como se o sujeito cognoscente transitasse em mão única para um universo de abstrações, negligenciando a concretude do mundo: "a ciência manipula as coisas e renuncia a habitá-las" (MERLEAU-PONTY, 2004b, p. 13). Essa condição pode ser contraposta a partir da consideração do mundo anterior a qualquer representação. Esse mundo que habitamos é o mundo vivido, que é conosco em associação, como coloca Merleau-Ponty em O Olho e o Espírito (2004a, p. 33, grifo meu), “eu não o vejo [o espaço] segundo seu envoltório exterior, vivo-o por dentro, estou englobado nele. Pensando bem, o mundo está ao redor de mim, não diante de mim". Ao estar com o mundo, o sujeito deixa de analisá-lo como um externo e passa a fazer parte dele, com todos os seus fenômenos, desdobramentos e possibilidades: "não se trata mais de falar do espaço e da luz, mas de fazer falarem o espaço e a luz que estão aí" (MERLEAU-PONTY, 2004a, p. 33), ou seja, não é o ser intelectualmente analisando os fenômenos que se apresentam, mas vivenciando-os como "um igual". Não há a separação entre sujeito e objeto, estes são, no mundo, enquanto conjunto. A percepção que se dá nessa inserção é uma percepção primordial, em que todas as dimensões do percepiente estão em jogo, e não só sua capacidade de formular representações. É o que Ponty denomina, nas Notas do O visivel e o invisivel (MERLEAU-PONTY 1984, p. 197-198, nota de 22 de outubro de 1959), captura do ser bruto pelo espírito selvagem, de difícil compreensão pelo racionalismo científico, mas prática comum da experiência. Chauí (2002, p. 152-153) coloca o espirito selvagem como o espírito da práxis, que quer e pode alguma coisa, "o sujeito que não diz 'eu penso', mas 'eu quero" e age "realizando uma experiência e sendo essa própria experiência”. O ser bruto, por sua vez, é o ser "que não foi submetido à separação (metafísica e científica) entre sujeito e objeto, alma e corpo, consciência e mundo, percepção e pensamento".

Para que haja esse encontro com o mundo, torna-se ainda necessário um meio que nos leve, como sujeitos, a perceber e nos fazer 
sentir associados a ele. O elemento que torna possível a percepção através dessa associação é o nosso corpo. Porém não o corpo como uma exterioridade, uma ferramenta, que nos leve a experimentar o mundo, senti-lo para depois racionalizá-lo, como defende o racionalismo científico, mas uma "carne", uma materialidade que nos torna profundamente conectados com tudo o que nos cerca:

É preciso que o pensamento da ciência (...) torne a se colocar num 'há' prévio, na paisagem, no solo do mundo sensível e do mundo trabalhado tais como são em nossa vida, por nosso corpo, não esse corpo possível que é lícito afirmar ser uma máquina de informação, mas esse corpo atual que chamo meu, a sentinela que se posta silenciosamente sob minhas palavras e sob meus atos. (MERLEAU-PONTY, 2004a, p. 14)

É preciso, portanto, que se encontre não o corpo funcional, que é uma máquina externa à consciência, mas o corpo que sou eu, em conjunto com os movimentos do mundo: "é preciso reencontrar o corpo operante e atual, aquele que não é uma porção do espaço, um feixe de funções, que é um trançado de visão e de movimento" (MERLEAUPONTY, 2004a, p. 16). Para além disso, ainda cabe pontuar que, nessa perspectiva defendida por Merleau-Ponty, consciência e sensibilidade estão associadas através desse corpo, não podendo dissociarem-se, como o quer o pensamento científico: "imerso no visível por seu corpo, ele próprio visível, o vidente não se apropria do que vê; apenas se aproxima dele pelo olhar, se abre ao mundo" (MERLEAU-PONTY, 2004a, p. 16).

Encarando-se como uma parte do mundo, o sujeito não simplesmente olha, mas vê, e esse "ver" é muito mais profundo, enaltece todas as relações do ser com o que se lhe apresenta, não havendo a clássica distinção ente corpo e espírito: "o homem não é um espírito $e$ um corpo, mas um espírito com um corpo, que só alcança a verdade das coisas porque seu corpo está como que cravado nelas" (MERLEAU-PONTY, 2004b, p. 17-18, grifos do autor). A partir dessa apresentação, e no momento em que ele assume sua relação com o mundo, sente-se instigado a pensar sobre esse mundo, mas em conjunto com ele:

Há que compreender o olho como a 'janela da alma'. (...) É preciso que aquilo que é sem lugar seja adstrito a um corpo, e mais: seja iniciado por ele a todos os outros e à natureza. É preciso tomar ao pé da letra o que nos ensina a visão: que por ela tocamos o sol, as estrelas, estamos ao mesmo tempo em 
toda parte, tão perto dos lugares distantes quanto das coisas próximas, e que mesmo nosso poder de imaginarmo-nos alhures [...], de visarmos livremente, onde quer que estejam, seres reais, este poder recorre ainda à visão, reemprega meios que obtemos dela. Somente ela nos ensina que seres diferentes, 'exteriores', alheios um ao outro, existem, no entanto, absolutamente juntos, em simultaneidade. (MERLEAU-PONTY, 2004a, p. 42-43, grifo do autor)

Nesse movimento de encarnar o sujeito no mundo vivido através da vivência de sua corporeidade, a percepção estética e a expressão artística ganham importante significado. A experiência estética e a arte possibilitam o reavivamento da dimensão sensível do ser humano. Nelas, o sujeito se conecta ao objeto, não havendo a postura analítica imperativa sobre o mundo. Ele se despoja de todos os preconceitos que possa ter, deixa de lado qualquer tipo de pré-compreensão que possa existir e se insere nos fenômenos, dando vazão à busca da essência das coisas. Uma característica fundamental da experiência estética é que ela "é, de fato, a percepção real, aquela que só quer ser percepção, sem se deixar seduzir pela imaginação que convida a vaguear em torno do objeto presente, ou pelo intelecto que, para dominar o objeto, procura reduzi-lo a determinações conceituais" (DUFRENNE, 1972, p. 80).

Nesse sentido, por meio dessa percepção real, é possível se acessar as dimensões não-racionalizáveis do ser humano, em que se pode sentir sem a necessidade de conceituar esse sentimento (DUARTE, 1981, p. 84): "Na experiência estética retornamos àquela percepção anterior à percepção condicionada pela discursividade da linguagem; retornamos a uma primitiva e mágica visão do mundo”.

Assim também podemos considerar a arte como primordial na relação do ser com o mundo, na medida em que ela não procura relações com causas intelectivas ou trabalhadas mentalmente, mas sim uma apreensão do mundo, primeira, global, que simplesmente seja trabalhada pelo corpo como todo, sem limitá-la, na tentativa de traduzi-la em conceitos formais. A arte não é construção, artifício, relação industriosa a um espaço e a um mundo de fora. É realmente o "grito inarticulado" que desperta, na visão ordinária das forças adormecidas, um segredo de preexistência (MERLEAU-PONTY, 2004a, p. 37). Seu espaço está justamente onde a representação não pode adentrar, o que justifica a questão de Ponty sobre a expressão do mundo não ser sujeita à prosa dos 
conceitos: “(...) já que a percepção nunca está acabada, já que as nossas perspectivas nos dão para exprimir e pensar um mundo que as engloba, as ultrapassa e anuncia-se por signos fulgurantes como uma palavra ou um arabesco, por que a expressão do mundo seria sujeita à prosa dos sentidos ou conceitos?" (MERLEAU-PONTY, 2004a, p. 82, grifo do autor).

Não há relação de causalidade intelectiva entre a obra de arte, a visão estética e a visão utilitarista, simplesmente o sujeito consegue visualizar a profundidade e a sua relação com o mundo através da obra, como coloca Duarte (1981, p. 84): “na percepção estética não é mais a intelecção que guia o nosso perceber. A 'verdade' do objeto reside nele mesmo: não se buscam relações como outros objetos nem se pergunta acerca de sua utilidade".

Esse olhar primordial e a vivência poética do mundo é o que, portanto, a arte pode ensinar, o que tem importância inquestionável nos dias atuais para a educação ambiental. Os estranhamentos que o ambiente tem causado a seres humanos que possuem, por natureza, uma necessidade estética, e que têm perdido suas conexões com a vida, seu reconhecimento da própria corporeidade e seus enraizamentos nos lugares habitados parecem resultar em discursos de responsabilidade socioambiental que não encontram mudanças efetivas nos modos de viver. Não há possibilidade de comprometimento com aquilo a que o sujeito não está ligado por laços de afetividade e por significações fundadas em vivências e histórias de vida.

Essa característica faz com que, intrinsecamente, a percepção estética traga um caráter de eticidade, já que, ao perceber-se no mundo vivido e aproximar-se dele pela arte, o sujeito naturalmente consegue despertar uma atitude responsável em relação ao que vivencia, pois se sente em união com o mundo: "As decisões mesmas que nos transformam são sempre tomadas em relação a uma situação de fato, e uma situação de fato pode ser aceita ou recusada, mas nunca pode deixar de nos fornecer nosso impulso e de ser ela própria, para nós, como situação 'a aceitar' ou 'a recusar', a encarnação do valor que lhe damos" (MERLEAU-PONTY, 2004a, p. 142). 


\section{A educação estética ambiental}

A educação estética ambiental parte do princípio de que somente um novo tipo de relação entre ser humano e ambiente poderá efetivamente formar indivíduos aptos ao enfrentamento das problemáticas socioambientais que vivenciamos. Desde que o ser humano foi expurgado da natureza, considerando-se um ente superior a ela, devendo dominá-la e desbravá-la com vistas ao progresso e ao desenvolvimento da sociedade, muito se perdeu da real natureza humana ligada intimamente ao ambiente do qual fazemos parte e do qual não devemos, nem podemos em essência, nos separar.

A educação estética ambiental considera que essencialmente estamos unidos à natureza, ao mundo, ao lugar habitado e que, se queremos atitudes maduras, ambientalmente corretas e eticamente responsáveis, não há como obtê-las partindo-se unicamente da ciência alicerçada na dimensão racional, e nem tampouco de discursos que não levem em consideração as histórias de vida e as vivências concretas dos sujeitos. Se a base de onde surge a relação ser humano-ambiente é o mundo da vida ou, como princípio, a natureza, o local onde se deve buscar essa nova relação é inicialmente na relação com o mundo. Ou seja, nenhuma educação será efetivamente ambiental - e nem mesmo educação - se não partir da realocação do ser humano no mundo. Como coloca Dufrenne (1969, p. 192), “(...) ser parte da Natureza, não é ser coisa em meio às coisas no universo do positivismo e muito menos estar no mundo como seu correlato transcendental; é estar enraizado no real". Esse enraizamento no real de que trata o autor nada mais é do que a reinserção do ser humano no mundo da vida. A partir do momento em que o ser humano pode vivenciar esteticamente o mundo que habita, sendo transpassado pelas diversas percepções que daí resultam, ele estará preparado para compreender, e não simplesmente aceitar, as atitudes maduras, ambientalmente corretas e eticamente responsáveis.

O que a educação estética ambiental pode fazer é possibilitar ao ser humano a consciência da parte que ocupa na complexidade do mundo e, assim, tirar-lhe a sensação angustiante de vazio imposta por um modo de vida que não lhe traz respostas e identificações e possibilita a ele reconhecer-se e reposicionar-se, como coloca Dufrenne (1969, p. 207): “o homem realiza sua natureza ao integrar-se na Natureza ou, antes, ao compreender que está integrado nela”. 
A arte nos ensina a perceber poeticamente o mundo e a nos identificarmos com ele: "na experiência estética os meus sentimentos descobrem-se nas formas que lhes são dadas, como eu me descubro no espelho. Através dos sentimentos identificamo-nos com o objeto estético, e com ele nos tornamos um" (DUARTE, 1981, p. 85).

No momento em que o ambiente, a natureza se configura como objeto estético passível de significação através da arte, ela me torna possível essa identificação que menciona Duarte, despertando minha relação com o mundo vivido, com o ambiente ${ }^{3}$ do qual faço parte e que sou levado frequentemente a esquecer. Nessa identificação de cumplicidade, passo a sentir todas as relações entre eu e os outros, entre eu e a natureza, que, a partir desse momento, ganham outros significados, deixando de ser presença bruta sem sentido para mim.

(...) a natureza me fala e eu a escuto. (...) E ao me falar de si, ela me fala de mim; não que ela me restitua a mim mesmo, à minha história ou à minha singularidade; nem mesmo que ela me ensine explicitamente minha humanidade: a experiência do céu estrelado é análoga, mas não solidária, à experiência da lei moral; o céu estrelado não me diz que eu seja razão ou capaz de razão. Mas ele me diz, ao menos que essa presença imensa é uma presença para mim, eu que estou, portanto secretamente ajustado a esta imensidade. (DUFRENNE, 1972, p. 76)

Ao educar a sensibilidade, a partir dessa relação afetiva entre ser humano e ambiente, também a relação do ser humano com seu igual é ressignificada, desenhando um novo sentido do agir ético. Avançar da dimensão essencialmente discursiva presente na educação ambiental para a dimensão vivencial: eis o aporte da educação estética ambiental.

Já são claras, no campo da educação ambiental, as necessidades de atuação frente às problemáticas ambientais enfrentadas. Esse reconhecimento é identificado nos discursos recorrentes. Com muito esforço foi possível ao ser humano chegar, com base no modelo de pensamento que atualmente temos em voga, a considerações efetivas acerca dos problemas, amplamente ventiladas nos discursos ambientais, porém ainda há um distanciamento entre a discursividade e as ações práticas buscadas. A educação estética ambiental vem descaracterizar esse distanciamento quando traz materialidade à discursividade já alcançada, possibilitando posturas pró-ativas, ressignificadas a partir de vivências 
concretas, refletidas, e não somente copiadas e replicadas. Cabe mencionar ainda que a discursividade já alcançada pela educação ambiental necessita estar sempre sendo ampliada e revisitada, pois os discursos oponentes que buscam miná-la são frequentes e também evoluem.

\section{0 teatro do oprimido}

$\mathrm{O}$ teatro, assim como qualquer modalidade artística, tem por princípio a atenção à dimensão sensível do humano, esta que já se revela no momento da percepção, anterior a qualquer racionalização. Nesse sentido, ele pode colocar numa linguagem essencialmente humana as significações recriadas da leitura vivencial do mundo. É nesse sentido que ele pode ser tomado como um agir educativo e que, consequentemente, pode ser ligado intrinsecamente à educação ambiental.

Inicialmente, deve-se considerar que o teatro não é uma criação humana puramente racional; ele sim está presente em intimidade orgânica e biológica com tudo o que se possa considerar humano. Augusto Boal, criador do teatro do oprimido, vai mais além nessa concepção de teatro que trazemos, colocando que o teatro é a primeira invenção humana, sendo que, por meio dele, o ser humano torna-se capaz de todas as outras invenções e descobertas. Essa consideração baseia-se na ideia de que o teatro possibilita ao ser humano ver-se em ação e, a partir disso, descobrirse como indivíduo, limitar e analisar suas possibilidades e potencialidades. Segundo Boal, o ser humano é o único animal capaz de desenvolver esse exercício de abstração e autoconsciência:

Teatro - ou teatralidade - é aquela capacidade ou propriedade humana que permite que o sujeito se observe a si mesmo, em ação, em atividade. $\mathrm{O}$ autoconhecimento assim adquirido permite-lhe ser sujeito (aquele que observa) de um outro sujeito (aquele que age); permite-lhe imaginar variantes ao seu agir, estudar alternativas. O ser humano pode ver-se no ato de ver, de agir, de sentir, de pensar. Ele pode se sentir sentindo, e se pensar pensando. (BOAL, 1996, p. 27, grifos do autor)

No sentido expresso pelo autor, o ser humano é ator e espectador de si mesmo, age e, no mesmo momento em que age, se visualiza agindo, ou seja, tem a possibilidade de visualizar sua ação e de ter 
consciência de que esta ação parte dele e ele pode modificá-la o quanto queira, quer realística ou imaginativamente. Assim, torna-se possível o desenvolvimento cultural e estrutural do ser humano em sociedade, no momento em que ele se visualiza como uno e vê o alter no outro.

Toda construção do teatro do oprimido baseia-se nessa prerrogativa básica que permite a construção de um sistema teatral diferenciado, centrado na desprivatização do teatro, pois, sendo o ser humano essencialmente teatral, todos devem ter a oportunidade de desenvolver essa capacidade: "É necessário derrubar os muros! Primeiro, o espectador volta a representar, a atuar: teatro invisível, teatro foro, teatro imagem, etc.” (BOAL, 2005, p. 177, grifo meu). O que se busca no teatro do oprimido é resgatar essa condição adormecida que nos acompanha e que possibilitaria, se desperta, a autonomia frente aos problemas enfrentados na realidade concreta.

Importa ressaltar que o estímulo para que esse construto fosse gerado e a base de todas essas técnicas e considerações se inserem no campo social. O teatro do oprimido busca a resolução ou, antes disso, a visualização dos problemas sociais e políticos que oprimem os sujeitos e que necessitam ser resolvidos. $\mathrm{Na}$ busca de resolução, uma "arma" fundamental é o teatro: "o Teatro do Oprimido, em todas as suas formas, busca sempre a transformação da sociedade no sentido da libertação dos oprimidos. É ação em si mesmo, e é preparação para ações futuras" (BOAL, 2005, p. 19, grifo do autor).

Para que se processe esse mecanismo de buscar a atuação adormecida que nos acompanha enquanto seres humanos, o teatro do oprimido apresenta uma série de etapas que visam ao despertar da atuação. Porém, para que esse processo possa se realizar, é necessário que nosso corpo esteja apto a despertar e aceitar a condição interpretativa, já que, na vida cotidiana e limitada em que vivemos, nosso corpo paulatinamente se atrofia e mecaniza, temos mecanizados as emoções, as sensações, os movimentos e os gestos:

(...) como podemos esperar que as emoções se manifestem livremente através do corpo do ator, se tal instrumento (nosso corpo) está mecanizado, muscularmente automatizado e insensível em $90 \%$ das suas possibilidades? Uma nova emoção, quando a sentimos, corre o risco de ser cristalizada pelo nosso comportamento mecanizado, pelas nossas formas habituais de ação e expressão. É como se vivêssemos dentro de escafandros musculares: seja qual 
for a emoção que sentirmos dentro dessa vestimenta, nossa aparência exterior será sempre a do escafandro. (BOAL, 2006, p. 59-60, grifo do autor)

Sendo assim, o primeiro passo para que os seres humanos resgatem o teatro é resgatar seus próprios corpos:

(...) para que se possa dominar os meios de produção teatral, deve-se primeiramente conhecer o próprio corpo, para poder depois torná-lo mais expressivo. Só depois de conhecer o próprio corpo e ser capaz de torná-lo mais expressivo, o "espectador" estará habilitado a praticar formas teatrais que, por etapas, ajudem-no a liberar-se de sua condição de "espectador" e assumir a de "ator", deixando de ser objeto e passando a ser sujeito, convertendo-se de testemunha em protagonista. (BOAL, 2005, p. 188, grifos do autor)

Após o necessário trabalho de desmecanização, o que nos torna mais expressivos e abertos a estímulos que possam reverberar em nossos corpos, o sujeito pode começar a passar pelas etapas que o levarão às práticas teatrais. Boal divide essas etapas em quatro: Conhecimento do corpo, tornar o corpo expressivo, o teatro como linguagem e o teatro como discurso. Nessas etapas de busca teatral, a metodologia utilizada em todas as técnicas da poética e do teatro do oprimido traz o aspecto lúdico do jogo, sendo que nada é feito simplesmente discursivamente, o que não teria o sentido buscado. Assim, todas as etapas partilham a aplicação de jogos que trabalham o par razão-emoção através da sensibilização.

Em todas essas etapas cabe ressaltar que o teatro do oprimido trabalha com as imagens do real, traz para o teatro os problemas vivenciados pelos sujeitos, traduzidos em imagens estetizadas para poderem ser analisadas e "virtualmente" resolvidas no contexto do teatro. Porém, isso pode ser feito por qualquer metodologia teatral. O diferencial do teatro do oprimido é que as pessoas se colocam frente aos problemas não somente como espectadores e, sim, como espect-atores ${ }^{4}$. (...) A linguagem, buscando a resolução deles em cena, não simplesmente analisando uma resolução previamente ensaiada pelos atores e apresentada, mas eles mesmos colocando suas vontades em cena, traduzindo seus discursos em atos e aplicando-os no momento estético, ensaiando a ação real através da aplicação da liberdade teatral: 
(...) e essa liberdade, oferecida aos espectadores pelo Teatro do Oprimido, é o que vai permitir que estes mesmos espectadores - e não os artistas em seu lugar - analisem e estudem os rituais aos quais estão submetidos em suas vidas e que, criativamente, substituam rituais e performances por outros mais adequados a lhes proporcionar a felicidade que é, afinal, o que mais queremos na vida. (BOAL, 2003, p. 76)

A vantagem que se coloca no teatro do oprimido é que se torna possível a visualização estática dos problemas que, na realidade, fluem. No momento em que se consegue paralisá-los em cena, torna-se possível a análise mais aprofundada deles e, assim, os indivíduos sentem-se mais à vontade para exercitar novos comportamentos frente a esses problemas, fato que, na realidade, não aconteceria, pois a vida demanda posições rápidas, sem uma análise anterior aprofundada:

(...) o sucesso do Teatro do Oprimido em todo o mundo se deve justamente ao fato de que, ao apresentar imagens da realidade - imagens que podem ser transformadas, recriadas em outras imagens desejadas -, o Teatro do Oprimido retira destas representações a violência estratificada que elas contêm: congela o rio, permitindo, de forma serena, o exercício da inteligência e da criatividade dos espectadores que são chamados a inventar realidades possíveis, libertando-se da condição de meras testemunhas de rituais aceitos. (BOAL, 2003, p. 76)

\section{A educação estética ambiental e o teatro do oprimido em diálogo}

Como visto, o teatro do oprimido age inicialmente na consideração de que o teatro é uma construção humana e que todos nós somos atores, ou seja, busca a redemocratização do teatro:

O teatro do oprimido é teatro na acepção mais arcaica da palavra: todos os seres humanos são atores, porque agem, e espectadores, porque observam. Somos todos espect-atores. (...) A linguagem teatral é a linguagem humana por excelência, e a mais essencial. Sobre o palco, a toda hora e em todo lugar. Os atores falam, andam, exprimem idéias e revelam paixões, exatamente como todos nós em nossas vidas no corriqueiro dia-a-dia. A única diferença entre nós e eles consiste em que os atores são conscientes de estar usando essa linguagem, tornando-se, com isso, mais aptos a utilizá-la. Os não-atores, ao contrário, ignoram estar fazendo teatro, falando teatro, isto é, usando a linguagem teatral. (BOAL, 2005, p. ix) 
Nessa busca, ao sugerir que o teatro possibilita a autorreflexão, Boal o considera uma maneira de levar à transformação das condições do mundo em que vivemos. Essa transformação é que levará à construção da liberdade:

Creio que o teatro deve trazer felicidade, deve ajudar-nos a conhecermos melhor a nos mesmos e ao nosso tempo. O nosso desejo é o de melhor conhecer o mundo que habitamos, para que possamos transformá-lo da melhor maneira. O teatro é uma forma de conhecimento e deve ser também um meio de transformar a sociedade. Pode nos ajudar a construir o futuro, em vez de mansamente esperarmos por ele. (BOAL, 2005, p. xi)

Ao considerar o teatro como um fenômeno humano, e não como algo exclusivo e pertencente a certos grupos com toda a preparação e atuação necessárias, ao transformar os anteriormente considerados receptores do fenômeno teatral em produtores dele, o teatro do oprimido aproxima-se muito da formação estética que pontuamos.

O que a Poética do Oprimido propõe é a própria ação! O espectador não delega poderes ao personagem para que atue nem para que pense em seu lugar: ao contrário, ele mesmo assume um papel protagônico, transforma a ação dramática inicialmente proposta, ensaia soluções possíveis, debate projetos modificadores: em resumo, o espectador ensaia, preparando-se para a ação real. [...] O espectador liberado, um homem íntegro, se lança a uma ação. (BOAL, 2005, p. 182, grifo do autor)

O que nos propomos quando defendemos a educação estética na formação do ser humano integral também é a libertação dos sujeitos da pseudorrealidade em que vivem, dominados por um modelo de sociedade e de conhecimento essencialmente fragmentário. Entre as considerações que fizemos objetivando superar essa condição, inicialmente, pontuamos a necessidade de reinserção do ser humano no mundo vivido, atentando para percepções primordiais que são desqualificadas e diminuídas pelo paradigma moderno.

O que Boal traz com a democratização da criação teatral é a inserção do sujeito no fenômeno teatral desde sua criação, passando pela construção e finalizando-se com a ação. Anteriormente, todo esse processo era-lhe exposto, quando já totalmente realizado, ou seja, como simplesmente a representação de um processo fechado. No momento em que o indivíduo se insere no processo de criação teatral, em que vivencia 
o fenômeno, ele se reinsere no mundo ali retratado e, a partir dessa inserção ensaística, fictícia, traz significação e materialidade para sua própria vida, para seus problemas, angústias e desconfortos, visualizando possibilidades de superação.

Ao considerarmos o processo metodológico que Boal desenvolve no teatro do oprimido, existem muitas concepções que vêm ao encontro do que trazemos como necessário a esta encarnação do ser humano no mundo. Primeiramente, a consideração da corporeidade. Referimos-nos à necessidade de se atentar ao corpo como materialidade essencial nessa realocação do ser humano no mundo da vida. O corpo sensitivo, corpo prolongamento, que é afetado pelas percepções latejantes do mundo. Boal traz como essencial a necessidade de se buscar a reharmonização do corpo e sua relação com o mundo, partindo da quebra da mecanização imposta aos indivíduos pelos modos de vida. Essa característica se faz necessária no teatro do oprimido, no sentido de levar os sujeitos a se perceberem como totalidade, perceberem as limitações que lhes são impostas e, a partir disso, poderem tornar a interpretação mais carnal, dar-lhe mais realismo, sempre buscando, através disso, o despertar para a identificação e a ação que tornam possível a transformação e a liberdade:

Podemos mesmo afirmar que a primeira palavra do vocabulário teatral é o corpo humano, principal fonte de som e movimento. Por isso, para que se possa dominar os meios de produção teatral, deve-se primeiramente conhecer o próprio corpo, para poder depois torná-lo mais expressivo. Só depois de conhecer o próprio corpo e ser capaz de torná-lo mais expressivo, o "espectador" estará habilitado a praticar formas teatrais que, por etapas, ajudem-no a liberar-se de sua condição de "espectador" e assumir a de "ator", deixando de ser objeto e passando a ser sujeito, convertendo-se de testemunha em protagonista. (BOAL, 2005, p. 188, grifos do autor)

Grande parte dos jogos presentes no teatro do oprimido atenta para a consideração da unidade corporal. Nos exercícios da série Caminhadas, essa busca se associa à relação do corpo com a forma de caminhar, que acabamos por mecanizar:

Entre todas as nossas mecanizações, a maneira de andar é, talvez, a mais freqüente. É verdade que temos nossa maneira individual de andar, muito particular em cada um de nós, sempre igual, quer dizer, mecanizada. (...) Mudar nossa maneira de andar nos faz ativar certas estruturas musculares 
pouco utilizadas e nos torna mais conscientes do nosso próprio corpo e de suas potencialidade. (BOAL, 2006, p. 102)

No momento em que se exercitam outras formas de caminhar, quebra-se um pouco das mecanizações impostas ao corpo e dá-se um passo no sentido do resgate da integralidade do ser humano. Essa série é composta por vários jogos, sendo que todos buscam formas não-habituais de se caminhar. Outra série de exercícios que buscam essa reunificação do corpo a partir do movimento é a da Gravidade (BOAL, 2006, p. 120). Ao relacionar os movimentos corporais, tomando conhecimento da força da gravidade como algo que nos mantém constantemente presos e imersos, várias mecanizações são desconstruídas e pode-se perceber melhor a relação do corpo com o mundo. Esse passo é fundamental na busca da integralidade do ser humano.

O jogo Roda de ritmo e movimento também parte da necessidade de se trabalhar com a desmecanização do ser humano, na busca da unidade a partir da corporeidade. Porém, nesse jogo, além do corpo em movimento, o autor propõe o som como parte do movimento. Ou seja, o sujeito, ao mesmo tempo em que problematiza sua relação com o corpo, também o faz com o som que acompanha o movimento, ampliando, assim, a percepção dos estímulos que o rodeiam. Outra característica desse jogo diz respeito ao poder da corporeidade como elo com o mundo vivido ou a possibilidade que ela traz de comunicação com o outro e com esse mundo vivido:

Os atores formam um círculo; um deles vai até o centro e executa um movimento qualquer, por mais insólito que seja, acompanhado de um som, tanto o som como o movimento dentro de um ritmo que ele próprio inventa. (...) Todos devem tentar reproduzir, o mais precisamente possível, tudo que eles são capazes de ver e ouvir: os mesmos movimentos, a mesma voz, o mesmo ritmo... Se uma mulher estiver no centro, os homens no círculo não devem executar a versão masculina do movimento, mas reproduzir exatamente aquilo que estejam percebendo. O que acontece então? Qual o mecanismo? Muito simples: ao tentar imitar a maneira do outro de se mexer, cantar, etc., nós começamos a desfazer nossas próprias mecanizações. Imitando os outros, estaremos reestruturando de várias maneiras diferentes (porque vários atores irão ao centro) nossa própria maneira de ser e de agir. Não se deve fazer uma caricatura, porque ela nos levará a fazer coisas diferentes, porém sempre da mesma forma rígida. Devemos tentar compreender, sentir, reproduzindo exatamente o exterior para melhor sentir o interior da pessoa que vai até o centro. (BOAL, 2006, p. 127 grifo do autor). 
Outra possibilidade eminente do teatro do oprimido diz respeito à sua perspectiva artística. Também já pontuamos que a arte é um meio pelo qual se pode perceber esteticamente, o que a torna essencial no movimento de reintegralização do ser humano e reinserção no mundo da vida. Além de possibilitar a apropriação pelos espectadores, sujeitos que, de certa forma, permaneciam alheios à produção teatral, também os que porventura não se sintam motivados a inserir-se na realização de um espetáculo de teatro do oprimido têm a possibilidade de vivenciar esteticamente uma criação artística que os aproxima, de certa forma, da realidade ali representada. Esse fato se torna potencializado, pois, mesmo não tendo motivação de participar, esses podem se identificar não somente com um caminho dramático, como ocorreria em um espetáculo tradicional, em que o roteiro é fechado e sempre o mesmo, mas com várias possibilidades de atuação e de enfrentamento das problemáticas representadas: "o ator deixa de interpretar o indivíduo e passa a interpretar o grupo; deixa de interpretar um texto já escrito, acabado, e passa a interpretar uma dramaturgia embrionária” (BOAL, 2005, p. 203).

A partir do vislumbre, muito mais enfático e real, que o "espect-ator" tem, ao entrar em cena, do problema ali representado, a partir da nova significação que pode dar às dificuldades que enfrenta no momento em que atua, de posse de todas as suas potencialidades corporais e expressivas, dá-se o despertar da criticidade através da visualização da situação opressiva que lhe é imposta. Esse despertar crítico é assentado em uma perspectiva ética, como fundamentamos anteriormente.

O caminho proposto pela educação estética ambiental, como visto, se inicia com a reinserção do sujeito no mundo vivido e chega à gênese do agir ético, ponto em que surge a criticidade. No momento em que o sujeito torna-se livre e autônomo, visualizando, porém, sua relação com o outro e com o mundo, abre-se espaço para que possa identificar e agir contra atitudes que enrijeçam sua subjetividade e limitem seus modos de viver.

O teatro do oprimido, como já evidenciado, também apresenta, como analisado, forte viés crítico de identificação às situações reprodutivistas da sociedade, tanto em sua fundamentação teórica quanto prática, embasada sempre no reconhecimento das situações limitantes das vivências dos sujeitos. Assim como na educação ambiental, toda árvore do teatro do oprimido se nutre e se expande da eticidade: "essa diver- 
sidade não é feita de técnicas isoladas, independentes, mas guardam estreita relação entre si, e têm a mesma origem no solo fértil da Ética (...)" (BOAL, 2005, p. 15). A ética de que fala o teatro do oprimido é a ética do encontro buscada pela educação estética ambiental. O teatro do oprimido é contra a pulverização da moral amorfa, que é simples transmissão: "moral se refere àquilo que é comumente aceito; ética ao que deveria ser, ao que queremos que venha a ser" (BOAL, 2003, p. 144). É essa ética que a educação deve buscar:

É necessário ajudar os jovens para que construam, esteticamente, o mundo ético no qual vivem e para criar imagens que o corporifiquem, para que possamos melhor entendê-lo e, depois, deixando-o cuidadosamente de lado, construir - sempre com estes mesmos jovens e não em lugar deles - outros mundos éticos subjuntivos -... e se? -, procurando igualmente entendê-los e compará-los com o triste mundo real onde habitam. (BOAL, 2003, p. 172, grifos do autor).

$\mathrm{Na}$ democratização do teatro proposta por Boal, o que se busca é a reapropriação da arte pelos sujeitos e o retorno da visualização de que o ser humano é arte. Nessa atitude, torna-se possível contestar criticamente construções que limitem o espaço subjetivo do ser humano a partir da desconsideração da concretude do mundo vivido, criando, assim, pseudorrealidades que incorporam os sujeitos. Nessa atitude de enfrentamento, a proposição de tornar o teatro novamente próximo da vida dos indivíduos, de se buscar, através da arte, a contestação das situações que limitam as potencialidades do ser, o teatro do oprimido encontra-se com a educação estética ambiental, que considera a arte e a vivência estética genuína, meios fundamentais para se modificar pseudorrealidades e situações enrijecedoras dos modos de viver.

Essas características comuns entre os dois campos em análise permitem-nos evidenciar grande possibilidade de trabalho em conjunto entre os dois campos em questão. Porém, ainda nos cabe salientar, mesmo que de forma sucinta, um ponto de distanciamento entre a educação estética ambiental e o teatro do oprimido. $\mathrm{Na}$ análise que fizemos, podese visualizar que os fundamentos em que se embasam tanto a educação estética ambiental quanto o teatro do oprimido busca-se contestar a cultura moderna que enrijece e distorce os modos de viver. Porém, a fundamentação que nutre cada uma das áreas é diferenciada. 
A educação estética ambiental visa a romper com esse modelo e com as práticas educacionais e recorrentes na educação ambiental que se servem dos fundamentos técnico-científicos, ainda com um forte ranço positivista e antropocêntrico, que permeia o discurso da modernidade: "percebemos a racionalidade cognitivo-instrumental ainda fortemente introjetada, traduzindo sentidos utilizados no campo ambiental que enfocam uma transcendência do domínio racional, dando-lhe uma validade universal e independente da prática social cotidiana" (TRISTÃO, 2005, p. 254-255).

Nesse sentido, busca romper também com a tendência, amplamente ventilada na educação ambiental, que traz exclusivamente o caráter crítico-emancipatório. Entendemos que essa apropriação, por mais revolucionária e contestatória que seja, não fornece, sozinha, os fundamentos necessários para que possam existir mudanças efetivas. Os discursos proferidos por essas correntes fracassam justamente por se manterem na esfera da discursividade pura, atenta somente aos conceitos e representações, não chegando à base sensível que necessita ser transformada. A educação estética ambiental não suprime a necessidade de um posicionamento crítico e contestatório em relação às problemáticas em questão, porém evidencia que esse posicionamento crítico emerge a partir de uma mudança mais basal. Essa mudança remete à busca pela redescoberta do potencial criativo e a sensibilidade do ser humano e ao reavivamento dos sentidos do mundo vivido. Ou seja, toda construção da educação estética ambiental está baseada na redescoberta da sensibilidade, que abre espaço para o afloramento de outras dimensões humanas, como já evidenciamos. É a partir desse passo inicial que se torna possível o verdadeiro posicionamento crítico, ancorado em uma atitude ética em relação à vida. A arte, nesse sentido, passa a ser vivência essencial na obtenção dos objetivos buscados pela educação estética ambiental.

O teatro do oprimido age de forma diferenciada frente a esses objetivos. Seus fundamentos trazem fortemente o viés críticoemancipatório, com forte influência marxista. Seguramente, esse posicionamento tem origem histórica e se justifica no surgimento do teatro do oprimido em meio à ditadura militar. Nesse cenário e no período em que se insere seu surgimento, o teatro do oprimido buscava no ideal socialistamarxista suas bases para a gênese de um novo modo de vida frente à expansão do capitalismo fortemente desenvolvimentista pregado pela 
ditadura militar, com grande exclusão da população em geral. Com isso, grande parte da construção que serve de base para o teatro do oprimido tem seu fundamento em um movimento que não acompanhou as mudanças na sociedade e manteve um discurso radical, sem efeitos claros quanto às transformações propagadas. Ou seja, o discurso revolucionário de insurgência coletiva frente às adversidades enfrentadas continua existindo:

O Teatro do Oprimido, em todas as suas formas, busca sempre a transformação da sociedade no sentido da libertação dos oprimidos. É ação em si mesmo e é preparação para ações futuras. "Não basta interpretar a realidade: é necessário transformá-la!" - disse Marx, com admirável simplicidade (BOAL, 2005, p. 19, grifo do autor).

Porém, mesmo tendo essa fundamentação, o teatro do oprimido acaba ampliando-se para além de seus fundamentos: configura-se como arte, é uma modalidade artística que se serve da vivência e democratização da experiência estética para chegar a seus objetivos. E é nesse ponto que abre espaços coerentes de diálogo com a educação ambiental.

\section{Considerações Finais}

Podemos considerar que os campos da educação estética ambiental e do teatro do oprimido apresentam muitas relações diretas. A gênese de um novo relacionamento com o mundo vivido a partir da religação com a concretude, a redescoberta de si, partindo-se da corporeidade, passando pela alteridade, até se chegar a uma problematização crítica, pautada na ética, do contexto social, está presente tanto na educação estética ambiental quanto no teatro do oprimido de forma muito parecida. A atitude pró-ativa que se origina nos indivíduos em uma educação baseada nas proposições do teatro do oprimido também é uma contribuição frente às desmotivações enfrentadas na educação ambiental. Os exercícios, jogos e atividades propostos pelo teatro do oprimido são carregados dos princípios que o norteiam e que têm muitas relações profundas com os da educação estética ambiental.

Com isso, podemos pontuar que as ações de educação estética ambiental, desenvolvidas conjuntamente com os jogos, exercícios e construções do teatro do oprimido, permitem contextualizar e materia- 
lizar as discussões acerca dos limites da educação vigente, especialmente as relacionadas às limitações impostas à criação de novas subjetividades e ao engessamento dos modos de viver dos sujeitos.

Evidenciamos também a presença de um distanciamento entre os dois campos que dizem respeito ao referencial no qual se baseia cada proposta, sendo que a educação estética ambiental tem em sua base a fenomenologia, fornecendo, em suas discussões, o enfrentamento que se faz pela visualização da positividade do mundo, enquanto o teatro do oprimido fundamenta-se num discurso crítico-emancipatório, trazendo discussões mais críticas e pautadas no enfrentamento das negatividades presentes na sociedade. Mas, seguramente, esses distanciamentos não anulam toda a contribuição que o teatro do oprimido pode fornecer à educação estética ambiental, indicando somente contornos que precisam existir na sua utilização.

\section{Referências}

BOAL, Augusto. O arco-iris do desejo. Rio de Janeiro: Civilização Brasileira, 1996.

BOAL, Augusto. O teatro como arte marcial. Rio de Janeiro: Garamond, 2003.

BOAL, Augusto. Teatro do Oprimido: e outras poéticas políticas. 7 ed. revisada e ampliada. Rio de Janeiro: Civilização Brasileira, 2005.

BOAL, Augusto. Jogos para atores e não-atores. 9 ed. Rio de Janeiro: Civilização Brasileira, 2006. CHAUÍ, Marilena. Experiência do pensamento: ensaios sobre a obra de Merleau-Ponty. São Paulo: Martins Fontes, 2002.

DUARTE Júnior, João Francisco. Fundamentos estéticos da educacão. São Paulo: Cortez, 1981. DUFRENNE, Mikel. O poético. Porto Alegre: Globo S.A., 1969.

DUFRENNE, Mikel. Estética e filosofia. Trad. Roberto Figurelli. São Paulo: Perspectiva, 1972. GADOTTI, Moacir. História das idéias pedagógicas. 3 ed. São Paulo: Ática, 1995

GAUDIANO, Edgar J. G. Educación ambiental: trayectorias, rasgos y escenarios. México/DF: UANL, Plaza Y Valdés, 2007.

LIMA, Gustavo da Costa. Questão ambiental e educação: contribuições para o debate. Ambient. Soc., Campinas, n. 5, dez. 1999. Disponível em

$<$ http://www.scielo.br/scielo.php?script=sci_arttext\&pid=S1414753X1999000200010 \&lng=pt\&nrm=iso $>$. Acesso em 7 jun. 2009.

MARIN, Andreia Aparecida. Teoria Estética e Educação Ambiental. 68 p. Monografia (Especialização em Filosofia e Existência), Universidade Católica de Brasília, Brasília, 2005. MARIN, Andreia Aparecida. A educação ambiental nos caminhos da sensibilidade estética. Inter-ação: Rev Fac Educ UFG, Goiânia v. 31,n. 2, p. 277-290, jul-dez 2006.

MARIN, Andreia Aparecida. Ética, estética e educação ambiental. Revista de Educ. PUCCampinas, Campinas, v. 22, p. 109-118, jun. 2007.

MARIN, Andreia Aparecida; OLIVEIRA, Haydée Torres; COMAR, Vito. Percepção 
imaginário e educação ambiental. OLAM, Rio Claro, v.5, n. 1, p. 188-201, maio 2005. MERLEAU-PONTY, Maurice. O visivel e o invisivel. Trad. José A. Gianotti e Armando M. Oliveira. São Paulo: Perspectiva, 1984.

MERLEAU-PONTY, Maurice. O olho e o espirito. Trad. Paulo Neves e Maria Ermantina Galvão Gomes. São Paulo: Cosac \& Naify, 2004a.

MERLEAU-PONTY, Maurice. Conversas. Trad. Fábio Landa e Eva Landa. São Paulo: Martins Fontes, 2004b.

STEINER, Rudolf. $A$ arte da educação. São Paulo: Antroposófica, 1988

TRISTÃO, Martha. Tecendo os fios da educação ambiental: o subjetivo, o coletivo, o pensado e o vivido. Educação e Pesquisa, São Paulo v. 31, n. 2, p. 251-264, maio/ago. 2005. Disponível em:

<http://www.scielo.br/pdf/ep/v31n2/a08v31n2.pdf> Acesso em 26/7/2008.

TRISTÃO, Martha. Os contextos da educação ambiental no cotidiano: racionalidades da/na escola. In: REUNLÃO ANUAL DA ANPED, 27, 2004, Caxambu. Anais... Caxambu, 2004.

\section{Notas}

${ }^{1}$ Ao falarmos da educação estética ambiental, mesmo tendo clara a redundância do termo, no sentido de que toda educação ambiental é estética por excelência, quando busca a vinculação do sujeito ao lugar habitado, sendo que, nesse espaço de construções coletivas, estão incluídos a natureza, o outro e o próprio sujeito, optamos por esta denominação como forma de garantir um campo de inserção e discussão da estética dentro da educação ambiental. Consideramos essa garantia necessária quando visualizamos muitas apropriações equivocadas e fragilizadas da perspectiva estética associada à educação e à educação ambiental. Além disso, essa denominação também possibilita uma identidade específica ao campo, fato que ocorre igualmente com o termo educação ambiental, pois, seguramente, a terminologia ambiental já deveria estar contemplada em uma educação que busque o desenvolvimento integral do ser humano.

2 Adotamos aqui o termo "clássico" como determinante do período nascido das correntes filosóficas racionalistas. Alguns pensadores tratam como "modernidade" tal período, incluindo a filosofia cartesiana e as subsequentes. No entanto, adotamos aqui a terminologia "modernidade clássica" ou, puramente, "período clássico", para nos referirmos ao contexto dos séculos XVII e XVIII e "modernidade" para o século XIX em diante, considerando a pós-modernidade como o esboço de um período histórico ainda não efetivamente instituído.

${ }^{3}$ Consideramos ambiente como lugar habitado, mundo vivido, espaço de construções coletivas, guardião de histórias de vida e elementos nostálgicos, campo aberto às expressões poéticas. Nele estão incluídos a natureza, o outro e ele mesmo, seu corpo.

${ }^{4}$ Termo criado por Augusto Boal para se referir aos espectadores que, no teatro do oprimido, são considerados como espect-atores, pois têm a possibilidade de passar da condição de "objetos" na ação teatral, ou seja, simples depositários do que o espetáculo lhes transmite, para a de sujeitos na ação teatral, podendo entrar em cena, substituindo os atores e buscando maneiras de enfrentar as problemáticas representadas. 
Recebido: 30/03/09

Aprovado: 14/08/09

Contato:

Rua Inácio Slompo, 170

Santa Felicidade

Curitiba - PR

CEP 82320-070 